\title{
ДИФЕРЕНЦАЛЬНА ДІАГНОСТИКА СТРИДОРОЗНОГО ДИХАННЯ В ПЕДІАТРИЧНІЙ ПРАКТИЦІ (огляд літератури та власні дані)
}

\author{
Національний медичний університет ім. О. О. Богомольця <yesipovas@gmail.com> \\ У статті звернено увагу на актуальність проблеми синдрому стридорозного дихання \\ у дітей. Детально висвітлено питання патогенезу, основні клінічні прояви стридору та \\ описано основні напрями диференціальної діагностики цього стану.
}

Ключові слова: стридор, бронхообструктивний синдром, діти.

Вступ. Однією з найнебезпечніших ситуацій в педіатричній практиці є розвиток у дітей першого року життя, особливо перших місяців, стану респіраторного дистресу [11, 18, 20- 22]. Існує помилкова думка, що стридор не вимагає звернення до лікаря і в подальшому проходить самостійно. На жаль, в більшості випадків це не так. Причинами стридора у дітей можуть бути різні патологічні стани: гострі захворювання інфекційного, алергічного та іншого генезу, генетично детерміновані захворювання (синдроми Дауна, П’єра - Робена, Марфана тощо), вади розвитку серцево-судинної системи, травного каналу, а також ізольовані аномалії будови гортані $[11,27]$. Стридорозне дихання у дітей першого року життя зазвичай має клінічні прояви з народження («вроджений стридор») або на першому місяці життя, але може дебютувати і в старшому віці. У частини хворих стридор зберігається і в старшому (до 7-10 років) віці і проявляється при навантаженнях і респіраторних інфекціях $[9,11]$.

Стридор є підставою для настороженості і ретельного нагляду. Він може бути однією з перших ознак розвитку загрозливої для життя обструкції верхніх дихальних шляхів. Тому здатність розрізняти численні типи дихальних шумів, особливо стридорозне дихання і дихання із свистом - stridor and wheezing, може бути однією з найважливіших навичок, що забезпечує своєчасне встановлення правильного діагнозу і визначає подальшу тактику ведення хворої дитини. Крім того, вкрай необхідним є не тільки виявлення анамнезу даного пацієнта, але і ретельне вивчення сімейного алергологічного та генетичного анамнезу [14, 17, 21, 22].

Розуміння педіатричної анатомії дихальних шляхів, вміння відрізняти локалізацію дихальних (респіраторних) шумів і лікувати з урахуванням їх етіології та патогенезу прискорюють діагностику і лікування відповідної патології.

Основна частина. Загальновідомі особливості верхніх дихальних шляхів у дітей і їх клінічне значення: тривале формування придаткових пазух носа, широта і зіяння євстахієвої труби, швидке втягнення в запальний процес лімфоїдних глоткових утворень та інші особливості. Однак існують особливості патофізіології середніх і нижніх дихальних шляхів, які призводять до виникнення стридорозного дихання і бронхообструктивного синдрому у дітей [3].

Відомо, що дихальні шляхи розподіляються на дві зони: верхні дихальні шляхи (виходять за межі грудної порожнини) - ротова і носова порожнини, глотка, гортань і проксимальна частина трахеї та нижні дихальні шляхи (ті, що знаходяться всередині грудної порожнини) - дистальна частина трахеї, бронхи, бронхіоли, дрібні дихальні шляхи і самі легені. I стридорозне (stridor), і свистяче (wheezing) дихання є дихальними шумами, що виникають в результаті обструкції 
в дихальних шляхах [3]. У разі звуження просвіту верхніх дихальних шляхів (знаходиться поза грудною порожниною) відбувається погіршення турбулентності під час вдиху і це призводить до стридору. Під час видиху явища стридорозного дихання часто зникають, тому що поштовх потоку повітря знизу може відкрити верхні дихальні шляхи, зменшуючи перешкоди для потоку. Стридор визначається як жорсткий, вібруючий звук різної висоти, викликаний турбулентним потоком повітря через звужені дихальні шляхи. Найчастіше стридор є результатом обструкції ділянок дихальних шляхів, які виходять за межі грудної порожнини. Таким чином, стридор - високочастотний, переважно інспіраторний дихальний звук, сформований екстраторакальною обструкцією верхніх дихальних шляхів $[16,25]$. Стридор, за словником Стедмана, визначається як «високий звуковий шум, що виникає під час вдиху або видиху, і є ознакою дихальної непрохідності». Причинами є круп, стороннє тіло, бактеріальний трахеїт, глотковий абсцес, алергічні реакції і епіглотит [26].

Однак якщо причина, що призводить до обструкції, досить серйозна або патологія поширюється і на частину трахеї, яка знаходиться всередині грудної порожнини, стридор може мати не тільки інспіраторний, але й експіраторний компонент. Найважливішою ознакою, що дозволяє визначити рівень обструкції, є фаза дихання, на якій стридор чути найкраще. За цією ознакою стридор можна розподілити на три типи: інспіраторний, експіраторний та двофазний [11].

Інспіраторний стридор зазвичай викликаний ураженням, що локалізується вище голосових складок і продукується колапсом м'яких тканин при негативному тиску під час вдиху $[3,24,27]$. Найчастішою причиною такого типу стридора $€$ ларингомаляція. Стридор при цій аномалії, як правило, є звуком низької висоти. Обструкція на рівні глотки зазвичай так само має інспіраторний характер, низьку висоту, однак відрізняється вологим звуком, схожим на хропіння: такий звук при диханні отримав назву стертор [20]. Стертор - звуковий сигнал, викликаний обструкцією на глотковому рівні через збільшення розмірів мигдаликів [18]. Медичний словник Стедмана визначає stertor як «важкий хропливий вдих, що виникає в комі або під час глибокого сну, іноді через обструкцію гортані або верхніх дихальних шляхів» [26]. Причинами стретору є стеноз хоан, збільшені мигдалини і/або аденоїди [14, 20].

Експіраторний стридор найчастіше виникає при звуженні нижніх відділів дихальних шляхів, часто його причиною є трахеомаляція.

Двофазний стридор, як правило, високий за тоном. Він викликаний ураженням на рівні голосових складок або підскладкового відділу. Найчастіше причиною двофазного стридора є парез/параліч голосових складок або вроджена мембрана $[11,24]$.

Стридор - музичний звук, який прослуховується без стетоскопа, при цьому переважно на вдиху. Зазвичай сила звуку така, що його чути на деякій відстані від хворого. Він виникає або тільки при глибокому диханні і в основному на вдиxy, або і на вдиху, і на видиху. Частота звуку становить 400-800 Гц, як і хрипів при астмі $[13,22]$. Стридор відрізняється більшою інтенсивністю звуку при аускультації ділянки гортані порівняно з грудною кліткою. Важливо відрізняти ці звуки від астматичних хрипів, отже, лікування неоднакове.

Непрохідність дихальних шляхів всередині грудної порожнини, як правило, проявляється як обструктивний wheezing синдром з аускультативною картиною сухих свистячих хрипів $[23,24]$. Обструктивний синдром розвивається в результаті звуження бронхів і називається wheezing - «свистяче на видиху дихання дітей». Механізм розвитку цього типу порушення дихання (задишка) такий. На вдиху бронхи, що знаходяться всередині грудної клітки, розширюються, як і альвеолярна тканина, під впливом внутрішньогрудного тиску, який нижчий за атмосферний. Разом з тим на видиху внутрішньогрудний тиск стає вищим за атмосферний і бронхи стискаються. Експіраторна задишка виражена тим сильніше, чим значніше запальне звуження бронхів і більший форсований видих. Такий механізм розвитку стридора визначають як внутрішньогрудний [3]. 
Маніфестуючи, як правило, на фоні гострої респіраторної інфекції, бронхообструктивний синдром (БОС) може бути проявом багатьох патологічних станів, найпоширенішими з яких є обструктивний бронхіт і бронхіальна астма (БА) [2, $8,10]$. Клінічні прояви БОС включають подовження видиху, збільшення частоти дихання, виникнення експіраторного шуму (свистяче, гучне дихання), приступи ядухи, участь допоміжної мускулатури в акті дихання, малопродуктивний кашель. В англомовній літературі цей клінічний симптомокомплекс отримав назву wheezing - синдром свистячого дихання (свистячі хрипи, які вислуховуються при аускультації або на відстані, є основним клінічним симптомом БОС) $[17,23]$

Отже, стридор - симптом, а не діагноз, він є не окремою нозологічною формою, а симптомом стенозу частіше верхніх дихальних шляхів, викликаним яким-небудь патологічним станом. Його може викликати ряд захворювань - від легкого ступеня тяжкості до загрозливих для життя станів [10, 11, 17, 27]. Тому дуже важливо виявити точну причину стридора у кожного конкретного пацієнта.

Стридор у дітей може бути вродженим і набутим, гострим і хронічним [5, 12 , 18]. Найчастіші причини гострого стридора такі:

- стенозуючий ларинготрахеїт (несправжній круп, стеноз гортані). Це найбільш поширена причина гострого стридора у дітей. Зазвичай виникає у віці від 6 міс до 2 років і характеризується «гавкаючим» кашлем, охриплим голосом, нетривалою лихоманкою і погіршенням стану вночі;

- вдихання (аспірація) стороннього тіла. Зустрічається досить часто, особливо у дітей у віці від 1 до 2 років. Симптоми розвиваються раптово, на фоні повного здоров'я, під час гри або їжі [7];

- заглотковий абсцес (характерний у віці до 6 років), рідше паратонзилярний (зазвичай виникає у підлітків). Заглотковий абсцес проявляється у болі при ковтанні і перерозгинанні шиї;

- епіглотит як причина стридора зустрічається набагато рідше від моменту впровадження вакцини проти Haemophilus influenza типу В. Клінічна картина характеризується прогресуванням симптомів стенозу на фоні вираженої дисфагії, лихоманки та інтоксикації [7].

Хронічний стридор у дітей найчастіше є наслідком вродженої патології, зокрема:

- $\quad$ ларингомаляція - найчастіша причина хронічного стридора у дітей. Зустрічається у новонароджених і дітей раннього віку. Стридор зазвичай посилюється в положенні лежачи, під час плачу і годування, а також на фоні ГРI [13, 15];

- д дисфункція голосових зв'язок (ДГЗ). Головний симптом - якісні порушення голосу: охриплість, зміни тембру або тональності, може супроводжуватися стридором внаслідок проходження повітря через звужений просвіт гортані при вдиху і видиху. У більшості випадків проходить самостійно в перші 2 роки життя. За даними авторів [1, 8, 12], анамнез пацієнта з дисфункцією голосових зв'язок може нагадувати перебіг у хворого бронхіальної астми (БА): утруднення дихання, хрипи і кашель під час контакту з іритантами або фізичного навантаження. Задишка при ДГЗ характеризується раптовим початком, короткою тривалістю (близько 2 хв) і мимовільним закінченням. Нерідко виявляють скарги на утруднення при вдиху в ділянці горла або верхній частині трахеї, а також на дистанційні хрипи на вдиху і видиху. У більшості хворих 3 ДГЗ раніше встановлювали діагноз БА і призначали глюкокортикостероїди (без ефекту або з мінімальним ефектом); близько 28 \% пацієнтів проводили інтубацію в зв'язку із задухою. Вік пацієнтів варіював від немовляти до 82 років, переважали жінки [1, 19];

- аномалії гортані: вроджені мембрани гортані (можуть призводити до двофазного стридору), дискінезія гортані, кісти гортані;

- трахеомаляція. Найчастіше викликається дефектами будови хрящів трахеї, рідше - зовнішнім їх стисненням. Це найчастіша причина стридора на видиху (експіраторний стридор); 
- подвійна дуга аорти є однією з аномалій, що утворює судинне кільце і викликає компресію трахеї та стравоходу. У грудних дітей основним проявом судинного кільця є стридорозне дихання від моменту народження або відразу після нього. При не встановленому вчасно діагнозі клінічні прояви ПдА зберігаються і прогресують. Одночасно спостерігають задишку, кашель, приступи задухи, апное, ціаноз, рецидивну пневмонію (через аспірацію їжі), відрижку, блювання, дисфагію, зниження маси тіла [4, 6];

- $\quad$ гіпертрофія піднебінних мигдалин може бути причиною стенозу верхніх дихальних шляхів внаслідок перешкоджання нормальному вдиху. Внаслідок обструкції на глотковому рівні через збільшення розмірів мигдаликів виникає звуковий сигнал, відомий як стертор [14, 18, 27]. Інспіраторна задишка посилюється вночі та супроводжується шумним диханням, хропінням і значним інспіраторним втягуванням надочеревини, грудини і міжреберних проміжків [25].

Власний досвід свідчить, що при аналізі нозологічних груп в структурі захворюваності у дітей, які пройшли лікування в ДКЛ № 3 за останні 5 років, превалювали хвороби органів дихання - 78,5%. Серед патології, що супроводжувалась обструкцією верхніх або нижніх дихальних шляхів, перше місце посідає обструктивний бронхіт (ОБ) - 17,2 \%, друге - гострий стенозуючий ларинготрахеїт (ГСЛТ) - 15,3 \%, БА становить $1,1 \%$.

У більшості дітей спостерігали типову клінічну картину і труднощів при діагностиці не виникало. Так, скарги на «гавкаючий» кашель, стенотичне (стридорозне) дихання, зміну тембру (від незначущої осиплості і до афонії), інспіраторну задишку на фоні виражених явищ гострих респіраторних інфекцій (ГРІ) та лихоманки свідчили на користь ГСЛТ. У 1,8 \% дітей спостерігали набряк гортані незапального характеру при алергічних реакціях негайного типу на харчові продукти (3 дитини) та пилкові рослини (2 дитини). У 1,3% дітей $з$ первинним діагнозом ГСЛТ після консультації ЛОР-лікаря і діагностики в спеціалізованому відділенні вже протягом першої доби встановлено наявність стороннього тіла.

Аналіз клінічної картини у дітей перших 2-3 міс з діагнозом ГРІ показав наявність шумного стридорозного дихання, храпу та завмирання під час сну, що часто турбує молодих батьків. Стридор, який виникає в такій ситуації, має транзиторний характер і зазвичай не є симптомом аномалії розвитку гортані, а пояснюється анатомо-фізіологічними особливостями. У дітей раннього віку ніс і носоглотковий простір малих розмірів, порожнина носа низька і вузька, гортань має лійкоподібну форму з чітким звуженням в ділянці підзв’язкового простору (у новонародженого до 4 мм), тому навіть незначні гіперемія і набряк слизової оболонки носа та підслизового шару підзв’язкового простору можуть викликати порушення дихання при незначних проявах респіраторної інфекції. Такі симптоми стридору проходять або зменшуються в процесі лікування основного захворювання [7, 13, 16]. Однак у разі стридорозного дихання необхідно виключати інші, серйозніші причини.

Значні труднощі виникали у випадках відсутності позитивної динаміки при проведенні адекватної терапії деяких дітей з явищами стридорозного дихання.

Наводимо клінічний випадок дитини віком 1 міс 12 днів, яку госпіталізовано до стаціонару із скаргами батьків на утруднене, переривчасте дихання, що з'явилось у дитини на третьому тижні життя. Симптоми посилились напередодні на фоні ГРІ. При госпіталізації стан середнього ступеня тяжкості через дихальні розлади, відмічали шумне дихання, ціаноз носогубного трикутника, задишку змішаного типу, непродуктивний кашель. Встановлено попередній діагноз обструктивного бронхіту, дихальної недостатності II ступеня тяжкості. При рентгенологічному дослідженні органів грудної клітки даних про пневмонію не виявлено, при УЗД серця встановлено функціонування овального отвору. В динаміці стан дитини не поліпшувався, зберігалося гучне дихання з ознаками дихальної недостатності, 
терапія була неефективною. Після консультації ЛОР-лікаря і пульмонолога зроблено припущення про вроджену патологію гортані і голосових зв'язок. Для виключення патології проведено комп'ютерну томографію (КТ) органів шиї. Висновок: КТ-ознаки звуження трахеї на рівні дуги аорти. Дитину переведено до спеціалізованого відділення, в якому після КТ з внутрішньовенним болюсним контрастуванням встановлено діагноз подвійної дуги аорти [6].

Ще троє дітей у віці 2-3 міс госпіталізовано до ДКЛ № 3 з діагнозом обструктивного бронхіту, в анамнезі у них було по два епізоди обструктивного бронхіту, які намагались лікувати амбулаторно. В клінічній картині відмічали шумне дихання, задишку змішаного типу, непродуктивний кашель. Оскільки терапія виявилась неадекватною, було призначено додаткові обстеження в спеціалізованому відділенні та встановлено діагнози: ларингомаляцію - у 2 дітей та аномалію гортані (вроджена мембрана гортані) - у 1 дитини.

Також цікаві клінічні випадки гіпертрофії мигдаликів III ступеня у 2 дітей (2 роки 8 міс та 3 роки), у яких на фоні ГРІ посилювались симптоми стридорозного дихання, інспіраторної задишки з втягненням грудини та надочеревини. Із схожою симптоматикою дітей госпіталізували до стаціонару 5-6 разів на рік; клінічні симптоми у вигляді хропіння, стридорозного дихання, що посилювались в горизонтальному положенні, не зникали навіть у період ремісіі. Стан дітей значно полегшився після проведення тонзилотомії.

3 урахуванням даних літератури [7, 12, 13, 16-18] та власного досвіду, вважаємо, що у разі стридорозного дихання необхідно визначити анамнез даного захворювання та диференціювати гострий або хронічний процес. Якщо симптоми гострі, то є підстави запідозрити гостру респіраторну інфекцію або алергічну реакцію. Якщо симптоми виникають періодично, слід встановити, в якому віці вперше вони з'явились, їх тривалість та провокуючі фактори - положення тіла, годування, ГРІ, алергени, фізична активність. При об'єктивному обстеженні насамперед необхідно встановити наявність і ступінь вираженості дихальної недостатності шляхом оцінки вітальних показників. На ступінь тяжкості дихальної недостатності вкажуть тахіпное, ціаноз, задишка, участь допоміжної мускулатури в акті дихання, низька сатурація за даними пульсоксиметрії. Крім того, слід звернути увагу на такі діагностично значущі симптоми, як «гавкаючий» кашель, осиплість (афонія) голосу, вимушене положення, гіперсалівація, алергічні реакції (висипання, набряк м'яких тканин, кропив'янка). При стабільному стані пацієнта слід провести огляд ротової порожнини та для диференціації інспіраторних і експіраторних шумів не тільки аускультацію легень, але й аускультацію в ділянках шиї, трахеї й носа $[5,16,18,25]$.

Залежно від характеру стридора, анамнезу захворювання, динаміки клінічної картини дитину необхідно направити або до оториноларинголога (інспіраторний і двофазний стридор) для огляду верхніх дихальних шляхів і гортані, або до торакального хірурга (експіраторний стридор) для проведення ендоскопічних методів дослідження (трахеобронхо-, мікроларинго-, фіброларингоскопія).

Висновки. Необхідність і значущість диференціальної діагностики синдрому стридора вимагають від лікаря правильної тактики. Для клінічної практики у випадках стридорозного дихання у дітей важливим є розуміння анатомофункціональних особливостей дихальних шляхів у дітей раннього віку, механізмів формування дихальних шумів з метою визначення рівня ураження за фазою стридора і супутніми симптомами (зригування, ціаноз). Для правильної діагностики необхідні ретельний збір анамнезу і проведення клінічного обстеження з визначенням тяжкості стану пацієнта та у разі необхідності консультування вузькими спеціалістами (ЛОР-лікар, пульмонолог) з призначенням додаткового обстеження - прямої або непрямої ларингоскопії, в деяких випадках бронхоскопії, рентгенографії або КТ органів шиї та грудної клітки. При підтвердженні вродженої патології гортані і трахеї пацієнти потребують консультації й обстеження в медико-генетичному центрі для виключення поєднаних вад розвитку органів декількох систем. 
Спи сок л і тератури

1. Бродская О. Н. Дисфункция голосовых связок // Журн. практ. пульмонологии. 2011. - № 3. - С. 41-42.

2. Зайцева О. В. Бронхообструктивный синдром в практике педиатра. Роль ингаляционной бронхолитической терапии // Новости медицины и фармации. - 2008. № $19 .-$ C. $12-13$.

3. Иванько О. Г. Иллюстрированные клинические лекции по пропедевтике детских болезней. - Запорожье: Запорож. гос. мед. ун-тет, 2007. - $282 \mathrm{c}$.

4. Исакова Ю. Ф. Детская хирургия национальное руководство. - ГЭОТАР-Медиа, 2009. - $1256 \mathrm{c}$.

5. Катилов А. В., Дмитриев Д. В., Дмитриева Е. Ю. Клиническая пульмонология детского возраста. - Винница: Новая кн., 2013. - 333 c.

6. Кривченя Д. Ю., Руденко С. О., Кривченя Т. Д. Судинні компресії трахеї та респіраторний дистрес-синдром. Діагностичні та тактичні проблеми // Хірургія дитячого віку. - 2008. - Т. V, № 2. - С. 6-15.

7. Майданник В. Г. Гострий обструктивний ларингіт (круп) у дітей; огляд сучасних клінічних рекомендацій // Междунар. журн. педиатрии, акушерства и гинекологии. - 2015. - Т. 7, № 3. - С. 38-49.

8. Новик Г. А, Петруничев А. Ю., Макарова И. В. Бронхиальная астма и врождённый стридор гортани у детей // Лечащий врач. - 2011. - № 2. - С. 79-81.

9. Петруничев А., Новик Г., Цветков Э. Врождённый стридор гортани: диагностика и лечение // Педиатрическая фармакология. -2011 . - № 8. - С. 78-82.

10. Охотникова E. H. Патогенетические особенности бронхообструктивного синдрома у детей и современные возможности неотложной терапии // Астма та алергія. 2013. - № 2. - C. 52-61.

11. Солдатский Ю. Л., Зайцева О. В., Онуфриeвa E. K. и др. Стридорозное дыхание у детей первого года жизни // Педиатрия. 2013. - № 1. - C. 69-74.
1. Brodskaya O. N. Disfunkciya golosovyh svyazok // Zhurn. praktich. pul'monologii. 2011. - № 3. - S. 41-42.

2. Zajceva O.V. Bronhoobstruktivnyj sindrom v praktike pediatra. Rol' ingalyacionnoj bronholiticheskoj terapii // Novosti mediciny i farmacii. - 2008. - № 19. - S. 12-13.

3. Ivan'ko O. G. Illyustrirovannye klinicheskie lekcii po propedevtike detskih boleznej. Zaporozh'e: Zaporozh. gos. med. un-tet, 2007. $-282 \mathrm{~s}$.

4. Isakova Yu. F. Detskaya hirurgiya nacional'noe rukovodstvo. - GEHOTAR-Media, 2009. - $1256 \mathrm{~s}$.

5. Katilov A. V., Dmitriev D. V., Dmitrieva E. Yu. Klinicheskaya pul'monologiya detskogo vozrasta. - Vinnica: Novaya kn., 2013. - 333 s.

6. Krivchenya D. Yu., Rudenko E. O., Krivchenya $T$. D. Sudinni kompresiï traheï ta respiratornij distres-sindrom. Diagnostichni ta taktichni problemi // Hirurgiya dityachogo viku. - 2008. - T. V, № 2. - S. 6-15.

7. Majdannik V.G. Gostrij obstruktivnij laringit (krup) u ditej; oglyad suchasnih klinichnih rekomendacij // Mezhdunar. zhurn. pediatrii, akusherstva i ginekologii. -2015 . - T. 7 , № 3. - S. 38-49.

8. Novik G. A, Petrunichev A. Yu., Makarova I. V. Bronhial'naya astma i vrozhdyonnyj stridor gortani u detej // Lechashchij vrach. 2011. - № 2. - S. 79-81.

9. Petrunichev A., Novik G., Cvetkov Eh. Vrozhdyonnyj stridor gortani: diagnostika i lechenie // Pediatricheskaya farmakologiya. 2011. - № 8. - S. 78-82.

10. Ohotnikova E. N. Patogeneticheskie osobennosti bronhoobstruktivnogo sindroma u detej i sovremennye vozmozhnosti neotlozhnoj terapii // Astma ta alergiya. - 2013. - № 2. S. 52-61

11. Soldatskij Yu. L., Zajceva O. V., Onufrieva $E$. K. i dr. Stridoroznoe dyhanie u detej pervogo goda zhizni // Pediatriya. - 2013. № 1. - S. 69-74.

12. Bew $S$. Acute and chronic airway obstruction // Anaesthesia Intensive Care Medicine. - 2006. Vol. 7. - P. 164-168.

13. Bouderoyns A., Claes J., Van de Heyning P. Clinical practice: an approach to stridor in infants and children // Eur. J. of Pediatrics. - 2010. - Vol. 169, N 2. - P. 135-141.

14. Donna M. D'Alessandro. What's the Difference Between Stridor and Stertor? https:// pediatriceducation.org/2008/03/24/whats-the-difference-between-stridor-and-stertor/ March 24, 2008.

15. Fauroux B., PigeotJ., Polkey M. Chronic Stridor Caused by Laryngomalacia in Children// Am. J. of Respiratory and Critical Care Medicine. - 2001. - Vol. 164, N 10. - P. 15.

16. Goldbloom R. B. Pediatric Clinical Skills. - Philadelphia, US, 2001. - 360 p.

17. Holinger L. D. Evaluation of stridor and wheezing. Pediatric laryngology and bronchoesophagology. - Philadelphia, Pa: Lippincott-Raven Press, 1997. - P. 41-48. 
18. Lakhanpaul M., MacFaul R., Werneke U., Armon K. Anevidence-based guideline for children presenting with acute breathing difficulty // Emergency Med. J. - 2009. - Vol. 26, N 12. P. 850-853.

19. Kenn K., Balkissoon R. Vocalcorddysfunction: whatdoweknow? // Eur. Respir. J. - 2011. Vol. 37, N 1. - P. 194-200.

20. Melissa G. Kress. Stridor, Stertorand Snoring. Common Pediatric Airway Problems. - 2012. Internet resource - http://healthcare professionals.sw.org/resources/docs/division-ofeducation/events/pediatric-subspecialty/2012-12/0815-StridorSterSnor-Kress.pdf.

21. Mount Jason, Uner Atilla, Shawn Kaku. Pediatric wheezing and stridor // Emergency medical services. - 2004. - Vol. 33, N 7. - P. 58-60.

22. Noble V. E., Bontempo L.J., Nadel E. S. Stridor// J. Emerg. Med. - 2000. - Vol. 19, N 2. - P. 183186.

23. Noble V. E. The Diagnosis of Wheezing in Children //Am. Family Physician. - 2008. - Vol. 77, N 8. - P. 1109-1114.

24. Panitch H. B. Wheezing and lower airway obstruction // A Practical. Guide to Pediatric Respiratory Diseases. - Philadelphia. - 1994. - P. 39-48.

25. Sidney Braman. Disorders of the Central Airways and Upper Airway Obstruction. // International medicine news. - 2016 http://www.mdedge.com/node/1971/path_term/21.

26. Stedman Thomas Lathrop. Stedman's medical dictionary for the health professions and nursing., 1853-1938.Illustrated 7th ed. Philadelphia: Wolters Kluwer/Lippincott Williams \& Wilkins, 2012.

27. Zoumalan R., Maddalozzo J. D. Holinger. Etiology of Stridor in Infants //Ann. of Otology, Rhinology \& Laryngology. - 2007. - Vol. 116, N 5. - P. 329-334.

\title{
ДИФФЕРЕНЦИАЛЬНАЯ ДИАГНОСТИКА СТРИДОРОЗНОГО ДЫХАНИЯ В ПЕДИАТРИЧЕСКОЙ ПРАКТИКЕ \\ (обзор литературы и собственные данные) \\ С. И. Есипова (Киев)
}

В статье обращено внимание на актуальность проблемы синдрома стридорозного дыхания у детей. Подробно освещены вопросы патогенеза, основные клинические проявления стридора и описаны основные направления дифференциальной диагностики этого состояния.

Ключевые слова: стридор, бронхообструктивный синдром, дети.

\author{
DIFFERENTIAL DIAGNOSIS OF STRIDOR BREATHING \\ IN PEDIATRIC PRACTICE \\ (review of the literature and own data) \\ S. Yesipova (Kyiv, Ukraine) \\ Bohomolets National Medical University
}

The article presents the importance of the problem syndrome stridor in children. The questions of pathogenesis, the clinical manifestations of the stridor and the main directions of differential diagnosis of this condition are described.

Key words: stridor, bronchoobstructive syndrome, children. 